hepatitis $\mathrm{B}$ infection interferon probably exerts its beneficial effect through the immune system, in chronic non-A non- $B$ infection the interferon acts directly on the virus infected hepatocytes.

These initial results are encouraging, and longer term study of these patients is being undertaken to see whether the histological picture of the liver improves in parallel to biochemical values and also whether the improvement persists after interferon has been discontinued. Preliminary studies suggest that, certainly in some patients, one year of continuous treatment may be successful in bringing about a permanent biochemical and histoiogical remission. Even if relapse does occur on stopping treatment, continuous low dose interferon, which is accompanied by comparatively minor side effects, may be an acceptable inconvenience in view of the high risk of cirrhosis that untreated patients run.

We thank Sister Mary Crossey for help in managing the treatment, Jane Wadsworth for expert statistical advice, and Wellcome Research Laboratories for supplying Wellferon.

\footnotetext{
1 Realdi G, Alberti A, Rugge M. Long-term follow up of acute and chronic non-A non-B hepatitis: evidence of progression to liver cirrhosis. Gut non-A non-B

2 Pappas SC, Hoofnagle JH, Young N, Straus SE, Jones EA. Treatment of
}

non-A non-B hepatitis with acyclovir: a pilot study. 7 Med Virol 1985;15: $1-9$.

3 Hoofnagle JH. Chronic hepatitis. The role of corticosteroids. In: Szmuness W, Alter HJ, Maynard JE, eds. Viral hepatitis - 1981 symposium. Philadelphia: Franklin Institute Press, 1982:573.

4 Thomas HC, Scully LJ. Anti-viral therapy in chronic hepatitis B infection. Br Med Bull 1985;41:374-86.

5 Hoofnagle JH, Muller KD, Jones B, et al. Treatment of chronic non-A non-B hepatitis with recombinant human alpha-interferon. $N$ Engl f Med 1986 315:1575-8.

6 Thompson B, Doran M, Lever AMI, Webster ADB. Alpha-interferon therapy or non-A non-B hepatitis transmitted by gammaglobulin replacemen therapy. Lancet 1987 ; i: $539-41$.

7 Dienstag JL. Non-A non-B hepatitis. I. Recognition, epidemiology and clinical features. Gastroenterology 1983;85:439-62.

$8 \mathrm{McDonald}$ JA, Caruso L, Karayiannis $\mathrm{P}$, et al. Diminished responsiveness of male homosexual chronic hepatitis B carriers with HTLV-III antibodies to male homosexual chronic hepatitis B carriers with HTLV

9 Pignatelli M, Waters J, Brown D, Thomas HC. HLA class I antigen on the hepatocyte membrane during recovery from acute hepatitis $B$ virus infection hepatocyte membrane during recovery from acute hepatitis B virus infection
and during interferon therapy in chronic hepatitis B infection. Hepatology 1986;6:341-53.

10 Vallbracht A, Flehmig B. Elimination of a persistent hepatitis A infection in cell cultures by interferon. In: Kirchner $\mathrm{H}$, Schellekens $\mathrm{H}$, eds. The biology of the interferon system 1984. New York: Elsevier, 1985:339-45.

11 Hoofnagle JH, Smedlie A, Mullen KD, et al. Treatment of chronic delta hepatitis with recombinant human alpha-interferon [Abstract]. Gastroenterology 1985;88:1665.

12 Lever AML, Thomas HC. Treatment of chronic hepatitis B infection. Clinics in Tropical Medicine and Community Diseases 1986;1:377-93.

13 Vallbracht A, Gabriel P, Maier K, et al. Cell-mediated cytotoxicity in hepatitis A virus infection. Hepatology 1986;6:1308-14.

14 Dienstag JL, Bhan AK, Klingenstein RJ, Savarese AM. Immunopathogenesis of tiver disease associated with hepatitis B. In: Szmuness W, Alter HJ, Maynard JE, eds. V'iral hepatitis-1981 symposium. Philadelphia: Franklin Institute Press, 1982:221-36.

(Accepted 28 October 1988)

\section{Department of \\ Gastroenterology, Hadassah University \\ Hospital, Jerusalem, Israel $\mathrm{D}$ Rachmilewitz, $\mathrm{MD}$, professor of medicine and head of department}

The investigators making up the international study group are listed at the end of this paper.

\title{
Coated mesalazine (5-aminosalicylic acid) versus sulphasalazine in the treatment of active ulcerative colitis: a randomised trial
}

\author{
D Rachmilewitz on behalf of an international study group
}

\section{Abstract}

Objective-To assess the safety and efficacy of a preparation of mesalazine (5-aminosalicylic acid) coated with a $\mathrm{pH}$ dependent resin (Eudragit $\mathrm{L}$ ) as compared with sulphasalazine in patients with active mild to moderate ulcerative colitis.

Design-Eight week randomised double blind parallel group study.

Setting-Forty six gastroenterology outpatient clinics in seven countries.

Patients - Two hundred and twenty patients aged 18-70 who met the following criteria: clinical activity index $\geqslant 6$ and endoscopic index $\geqslant 4$; no concomitant treatment for ulcerative colitis; no hypersensitivity to salicylates or sulphonamides. Of the 164 patients eligible for efficacy analysis, 87 received the coated preparation of mesalazine and 77 sulphasalazine. Most of the remaining patients (28 in each group) were ineligible for the efficacy analysis because of treatment with steroid enemas. All pretrial characteristics were comparable in the two treatment groups.

Interventions-Coated mesalazine (Mesasal) $1.5 \mathrm{~g}$ daily or sulphasalazine $3.0 \mathrm{~g}$ daily for eight weeks. Compliance monitored by pill counts.

End point-Clinical and endoscopic remission.

Measurements and main results-Clinical activity measured by daily diary cards, assessment by investigators, and laboratory findings. Endoscopic evaluation at week 8. After four weeks 50 of $\mathbf{7 0}$ patients $(71 \%)$ taking coated mesalazine and 38 of 58 $(66 \%)$ taking sulphasalazine had achieved remission of their disease by eight weeks remission rates were $74 \%(37 / 50$ patients) and $81 \%(35 / 43)$ in the two treatment groups respectively. Endoscopic remission at eight weeks was recorded in 20 of 41 patients
$(49 \%)$ taking coated mesalazine and 18 of $38(47 \%)$ taking sulphasalazine. There was a higher incidence of adverse events among patients taking sulphasalazine $(25 / 105 ; 24 \%)$ than among those taking coated mesalazine $(16 / 115 ; 14 \%)$.

Conclusion-Mesalazine coated with Eudragit L is a safe, logical alternative to sulphasalazine.

\section{Introduction}

Sulphasalazine has been a standard treatment for acute inflammatory bowel disease and for maintaining remission since Svartz discovered its anti-inflammatory properties in the 1940s. ${ }^{1-3}$ Its use, however, is limited by intolerance or hypersensitivity in up to one third of patients with the disease. ${ }^{4-6}$ Sulphasalazine is composed of 5-aminosalicylic acid and sulphapyridine joined by an azo bond. 5-Aminosalicylic acid (mesalazine) is the active moiety responsible for the therapeutic efficacy of the drug in ulcerative colitis, ${ }^{7-10}$ the sulphapyridine component (acting only as the vehicle for 5-aminosalicylic acid) evidently being responsible for most adverse effects. ${ }^{11-20}$

Though the exact mechanism of action is not clearly established, the anti-inflammatory properties of 5aminosalicylic acid are apparently related to its topical effects on the inflamed colonic mucosa. ' Inhibition of several mediators that may have a role in the pathogenesis of the inflammatory response might in part explain the therapeutic effects of 5-aminosalicylic acid. 5-Aminosalicylic acid inhibits the colonic formation of prostanoids, ${ }^{21}$ leucotriene $\mathrm{B}_{4},{ }^{22}$ leucotriene $\mathrm{C}_{4},{ }^{23}$ and platelet activating factor. ${ }^{24}$

To maximise efficacy and minimise toxicity the logical therapeutic approach is delivery of 5-aminosalicylic acid devoid of sulphapyridine to the diseased 
bowel. 5-Aminosalicylic acid is rapidly absorbed after oral ingestion and is therefore not available to act topically on the inflamed mucosa. ${ }^{25}$ To overcome this a preparation of 5-aminosalicylic acid coated with the $\mathrm{pH}$ dependent methacrylate polymer Eudragit L was developed. This preparation (Mesasal; Claversal) is stable at $\mathrm{pH}$ concentrations of less than 6.0 and is designed to release the active component in the terminal ileum and proximal colon. A study using radiolabelling with indium to monitor transit of

TABLE I-Scoring systems for clinical symptoms and endoscopic findings

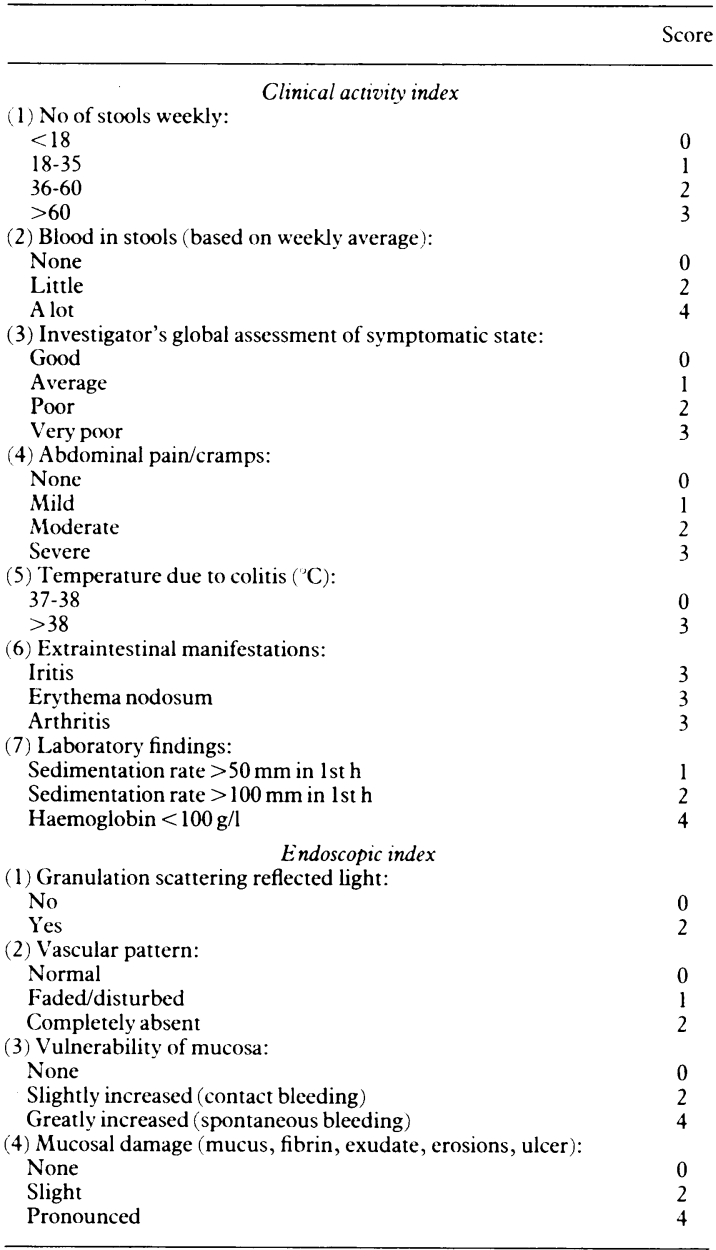

TABLE II - Demographic and pretrial characteristics of patients studied. Efficacy analysis

\begin{tabular}{|c|c|c|c|}
\hline & \multicolumn{2}{|c|}{ Treatment group } & \multirow[b]{2}{*}{ Significance } \\
\hline & $\begin{array}{l}\text { Coated mesalazine } \\
\qquad(\mathrm{n}=87)\end{array}$ & $\begin{array}{l}\text { Sulphasalazine } \\
\qquad(\mathbf{n}=77)\end{array}$ & \\
\hline No of men/No of women & $55 / 32$ & $48 / 29$ & $0 \cdot 642^{\star}$ \\
\hline \multicolumn{4}{|l|}{ Age (years): } \\
\hline $\begin{array}{l}\text { Mean }(S D) \\
\text { Range }\end{array}$ & $\begin{array}{l}38 \cdot 0(13 \cdot 4) \\
18-70\end{array}$ & $40 \cdot 4(14 \cdot 8)$ & $0 \cdot 2805 \dagger$ \\
\hline \multicolumn{4}{|c|}{ Duration of ulcerative colitis (years): } \\
\hline $\begin{array}{l}\text { Mean }(\mathrm{SD}) \\
\text { Range }\end{array}$ & $\begin{array}{l}3 \cdot 6(4 \cdot 9) \\
0-30\end{array}$ & $\begin{array}{l}5 \cdot 7(6 \cdot 8) \\
0-30\end{array}$ & $0 \cdot 0948 \ddagger$ \\
\hline \multicolumn{4}{|c|}{ Extent of disease (No (\%) of patients): } \\
\hline Rectum/sigmoid & $23(26)$ & $20(26)$ & \multirow{4}{*}{$0 \cdot 297^{\star}$} \\
\hline Partial colon & $34(39)$ & $28(36)$ & \\
\hline Total colon & $4(5)$ & $6(8)$ & \\
\hline Unspecified & $26(30)$ & $23(30)$ & \\
\hline \multicolumn{4}{|c|}{ Disease description (No (\%) of patients): } \\
\hline Continuous & $45(52)$ & $34(44)$ & \multirow{3}{*}{$0 \cdot 143^{\star}$} \\
\hline Episodic & $41(47)$ & $40(52)$ & \\
\hline \multirow{2}{*}{\multicolumn{4}{|c|}{ Clinical activity index: }} \\
\hline & & & \\
\hline Mean (SD) & $7 \cdot 7(2 \cdot 1)$ & $7 \cdot 8(2 \cdot 1)$ & \multirow{2}{*}{$0.9863 \ddagger$} \\
\hline Range & $6-17$ & $6-15$ & \\
\hline \multicolumn{4}{|l|}{ Endoscopic index: } \\
\hline Mean (SD) & $8 \cdot 6(2 \cdot 1)$ & $8 \cdot 7(2 \cdot 2)$ & \multirow{2}{*}{$0 \cdot 8675 \ddagger$} \\
\hline Range & $4-12$ & $4-12$ & \\
\hline
\end{tabular}

*Cochran-Mantel-Haenszel statistics.

to Test.

tWilcoxon two sample test.
Mesasal through the gastrointestinal tract showed the reliability of delivery and release of 5-aminosalicylic acid. ${ }^{26}$ The type of Eudragit coating determines the location in the gastrointestinal tract at which 5-aminosalicylic acid is released. For example, Asacol, a formulation coated with Eudragit $S$, releases 5-aminosalicylic acid at a $\mathrm{pH}$ of $7 \cdot 0$, so is unlikely to benefit patients with small bowel disease."

This study assesses the value of the preparation coated with Eudragit L compared with sulphasalazine in patients with active mild to moderate ulcerative colitis. Throughout the report the trial preparation is referred to as coated mesalazine.

\section{Patients and methods}

An eight week randomised double blind parallel group study was conducted in collaboration with 46 centres in Belgium, France, Israel, Italy, Norway, South Africa, and Spain. Outpatients from gastroenterology clinics between the ages of 18 and 70 with active mild to moderate ulcerative colitis confirmed by colonoscopy were eligible. Only patients with a pretrial clinical activity index of $\geqslant 6$ and an endoscopic index of $\geqslant 4$ were enrolled. Table I shows the scoring systems for clinical symptoms and endoscopic findings. Criteria for exclusion from the study were pregnancy or lactation, symptoms of peptic ulcer, and concomitant treatment with oral and rectal corticosteroids, immunosuppressives, metronidazole, and sodium cromoglycate. In addition, patients with disease confined to the rectum, disease of bacterial origin, or toxic megacolon were not eligible. Other criteria for exclusion included colonic malignancy, abnormal laboratory values, and known hypersensitivity to salicylates or sulphonamides.

At the pretrial visit, in addition to medical history, physical examination, and colonoscopy, the patient's baseline disease state was scored. This index encompassed data from the previous week and included number of stools weekly, amount of blood in stools, abdominal pain or cramps, physician's assessment of patient's condition, body temperature, extraintestinal manifestations, erythrocyte sedimentation rate, and haemoglobin concentration. After written or oral informed consent was obtained eligible patients were dispensed either coated mesalazine (Mesasal) $1.5 \mathrm{~g}$ daily or sulphasalazine $3.0 \mathrm{~g}$ daily in a double blind manner using a double dummy technique. Drug supplies were centrally packaged, labelled, and randomised in blocks of four according to a predetermined list generated by a computer. Patients were instructed to begin treatment that day, to record symptoms on daily diary cards, and to return at two week intervals. A symptomatic assessment was completed at each biweekly follow up visit and mandatory repeat colonoscopy performed at the completion of eight weeks. Laboratory studies including complete blood count, liver and kidney function tests, and urine analysis were performed at each visit.

Statistical methods-The two treatment groups were compared with respect to demographic and pretrial assessment variables. A clinical activity index of $\leqslant 4$ during the study was taken as the main evidence of remission in the analysis of efficacy. Remission rates (prevalence rates) at each assessment period and the $95 \%$ confidence intervals were calculated and analysed for treatment differences by using Cochran-MantelHaenszel statistics controlling for effects of individual centres on both the intention to treat and evaluable populations of patients. Each component of the clinical activity index was analysed for treatment differences by the statistical methods described above. The mean clinical activity index and mean endoscopic index were analysed by the Wilcoxon rank sum test controlling for 
TABLE III - Demographic and pretrial characteristics of patients studied. Intention to treat analysis

\begin{tabular}{|c|c|c|c|}
\hline & \multicolumn{2}{|c|}{ Treatment group } & \multirow[b]{2}{*}{ Significance } \\
\hline & $\begin{array}{l}\text { Coated mesalazine } \\
\qquad(\mathrm{n}=115)\end{array}$ & $\begin{array}{l}\text { Sulphasalazine } \\
\quad(\mathrm{n}=105)\end{array}$ & \\
\hline No of men/No of women & $71 / 44$ & $61 / 44$ & $0 \cdot 365^{\star}$ \\
\hline \multicolumn{4}{|l|}{ Age (years): } \\
\hline Mean (SD) & $38 \cdot 7(12 \cdot 9)$ & $39 \cdot 5(14 \cdot 5)$ & \multirow{2}{*}{$0.6807 \dagger$} \\
\hline Range & $18-70$ & $18-69$ & \\
\hline \multicolumn{4}{|c|}{ Duration of ulcerative colitis (years): } \\
\hline $\begin{array}{l}\text { Mean (SD) } \\
\text { Range }\end{array}$ & $\begin{array}{l}4 \cdot 4(5 \cdot 7) \\
0-30\end{array}$ & $\begin{array}{l}5 \cdot 6(6 \cdot 4) \\
0-30\end{array}$ & $0.2029 \ddagger$ \\
\hline \multicolumn{4}{|c|}{ Extent of disease (No (\%) of patients): } \\
\hline Rectum/sigmoid & $32(28)$ & $26(25)$ & \multirow{4}{*}{$0 \cdot 221^{\star}$} \\
\hline Partial colon & $42(37)$ & $38(36)$ & \\
\hline Total colon & $5(4)$ & $9(9)$ & \\
\hline Unspecified & $36(31)$ & $32(30)$ & \\
\hline \multicolumn{4}{|c|}{ Disease description (No (\%) of patients): } \\
\hline Continuous & $56(49)$ & $43(41)$ & \multirow{3}{*}{$0 \cdot 062^{\star}$} \\
\hline Episodic & $57(50)$ & $59(56)$ & \\
\hline Unspecified & $2(2)$ & $3(3)$ & \\
\hline \multicolumn{4}{|l|}{ Clinical activity index: } \\
\hline Mean (SD) & $7 \cdot 8(2 \cdot 3)$ & $8 \cdot 0(2 \cdot 5)$ & \multirow{2}{*}{$0 \cdot 8604 \ddagger$} \\
\hline Range & $3-17$ & $5-15$ & \\
\hline \multicolumn{4}{|l|}{ Endoscopic index: } \\
\hline No studied & 107 & 95 & \multirow{3}{*}{$0.4975 \ddagger$} \\
\hline Mean (SD) & $8 \cdot 5(2 \cdot 1)$ & $8 \cdot 7(2 \cdot 2)$ & \\
\hline Range & $4-12$ & $4-12$ & \\
\hline
\end{tabular}

effects of different countries and using pretrial values as a covariate.

\section{Results}

Of the 220 patients who entered the trial, 164 were considered eligible for the analysis of efficacy. There were no differences between treatments with respect to pretrial characteristics when all patients (intention to treat) or evaluable patients were compared (tables II and III). Fifty six patients ( 28 in each treatment group) were excluded because of default or violations of protocol, treatment with steroid enemas being the main reason for exclusion (table IV). As a large proportion of patients in each treatment group failed to complete eight weeks (table V) or were not considered eligible for the analysis of efficacy, an intention to treat analysis was performed in addition to the main analysis.

TABLE IV-Reasons for excluding patients from analysis of efficacy

\begin{tabular}{lcc}
\hline & \multicolumn{2}{c}{ No of patients } \\
\cline { 2 - 3 } & $\begin{array}{c}\text { Coated mesalazine } \\
\text { treatment group } \\
(\mathrm{n}=115)\end{array}$ & $\begin{array}{c}\text { Sulphasalazine } \\
\text { treatment group } \\
(\mathrm{n}=105)\end{array}$ \\
\hline Reason for exclusion & 5 & 1 \\
$\begin{array}{l}\text { Clinical activity index }<6 \\
\begin{array}{l}\text { Ulcerative colitis confined to rectum } \\
\text { Non-compliance }\end{array}\end{array}$ & 3 & 3 \\
$\begin{array}{l}\text { Patient request } \\
\text { Treatment with corticosteroid } \\
\text { enemas }\end{array}$ & 4 & 9 \\
\hline Total & 15 & 1 \\
\hline
\end{tabular}

${ }^{\star}$ Default $=$ violated study protocol

†Non-compliance $=$ did not take study medication as instructed - that is, took fewer than $80 \%$ of prescribed tablets.

TABLE V-Reasons for early withdrawal from trial

\begin{tabular}{lcc}
\hline & \multicolumn{2}{c}{ No of patients } \\
\cline { 2 - 3 } Reason for early withdrawal & $\begin{array}{c}\text { Coated mesalazine } \\
\text { treatment group }\end{array}$ & $\begin{array}{c}\text { Sulphasalazine } \\
\text { treatment group }\end{array}$ \\
\hline Adverse event & 7 & 8 \\
Default & 4 & 2 \\
Insufficient therapeutic effect & 16 & 12 \\
Non-compliance & 8 & 3 \\
Patient's request & 3 & 36 \\
\hline Total & 38 & 36 \\
\hline
\end{tabular}

$\star$ Default $=$ violated study protocol

+Non-compliance $=$ took less than $80 \%$ of study medication; failed to attend for follow up visits.
RESPONSE TO TREATMENT

In both treatment groups a mean clinical activity index of $\leqslant 4$ (remission) was achieved by week 4 . The index remained below 4 in both groups for the remaining four weeks (table VI). The proportion of patients receiving each treatment who achieved remission was similar at each assessment period, and by week 4, 50 of 70 patients (71\%) taking coated mesalazine and 38 of $58(66 \%)$ taking sulphasalazine were in remission $(\mathrm{p}=\mathbf{0} \cdot 338)$ (table VII). After eight weeks 37 of 50 patients $(74 \%)$ and 35 of 43 patients $(81 \%)(p=$ 0.835 ), respectively, had achieved remission. Of those who did not achieve remission, a similar proportion $(14 \%)$ in each group experienced improvement (reduction) in their clinical activity index. Remission rates evaluated in all patients (intention to treat) showed no significant differences between treatments (week $8, p=$ 0.786 ) (table VIIIm (miniprint)). In addition, the proportion of these patients in remission was similar to the proportion in remission in the analysis of efficacy.

TABLE VI-Mean clinical activity index

\begin{tabular}{|c|c|c|c|}
\hline & \multicolumn{2}{|c|}{ Treatment group } & \multirow{2}{*}{$\begin{array}{l}\text { Significance } \\
\text { (Wilcoxon rank } \\
\text { sum test) }\end{array}$} \\
\hline & Coated mesalazine & Sulphasalazine & \\
\hline \multicolumn{4}{|l|}{ Before trial: } \\
\hline No studied & 86 & 77 & \\
\hline Mean & $7 \cdot 7$ & $7 \cdot 8$ & \\
\hline SD & $2 \cdot 1$ & $2 \cdot 1$ & \\
\hline Median & $7 \cdot 0$ & $7 \cdot 0$ & \\
\hline \multirow{2}{*}{\multicolumn{4}{|c|}{$\begin{array}{l}\text { Kange } \\
\text { Week 2: }\end{array}$}} \\
\hline & & & \\
\hline No studied & 82 & 71 & \\
\hline Mean & $5 \cdot 2$ & $5 \cdot 1$ & \\
\hline SD & $3 \cdot 1$ & $3 \cdot 5$ & 0.5789 \\
\hline Median & $5 \cdot 0$ & $4 \cdot 0$ & \\
\hline Range & $0-16$ & $0-17$ & \\
\hline \multicolumn{4}{|l|}{ Week 4: } \\
\hline No studied & 70 & 58 & \\
\hline Mean & $3 \cdot 8$ & $3 \cdot 7$ & \\
\hline SD & $3 \cdot 6$ & $2 \cdot 8$ & 0.5249 \\
\hline Median & 3.0 & $3 \cdot 0$ & \\
\hline Range & $0-21$ & $0-11$ & \\
\hline \multicolumn{4}{|l|}{ Week 6: } \\
\hline No studied & 60 & 48 & \\
\hline Mean & $3 \cdot 2$ & $2 \cdot 8$ & \\
\hline SD & $2 \cdot 8$ & $2 \cdot 7$ & 0.6592 \\
\hline Median & $3 \cdot 0$ & $2 \cdot 0$ & \\
\hline Range & $0-12$ & $0-10$ & \\
\hline \multicolumn{4}{|l|}{ Week 8: } \\
\hline No studied & 50 & 43 & \\
\hline Mean & $3 \cdot 1$ & $2 \cdot 7$ & \\
\hline SD & 3.3 & $3 \cdot 1$ & 0.8088 \\
\hline Median & $2 \cdot 0$ & $2 \cdot 0$ & \\
\hline Range & $0-13$ & $0-14$ & \\
\hline
\end{tabular}

The proportion of patients reporting fewer than 18 bowel movements a week increased at each assessment period from roughly $7 \%$ before the trial to over $50 \%$ by week $8(\mathrm{p}=0 \cdot 761)$ for both groups (table IXm). After eight weeks of treatment 26 of 50 patients $(52 \%)$ taking the coated preparation and 25 of $43(58 \%)(p=0.993)$ taking sulphasalazine reported absence of blood in their stools (table $\mathrm{Xm}$ ). The quality of stools also improved throughout the study in both treatment groups (table XIm). A significant difference $(p=0 \cdot 048)$ in favour of sulphasalazine was detected at week 2 , but by week 4 and for the remainder of the trial the incidence of patients reporting normal consistency of stools was similar in the two groups. No significant difference was detected between the two groups with respect to the number of patients suffering abdominal pain or cramps. The proportion of patients without pain increased during the trial in both groups, and by the end of eight weeks 31 of 50 patients $(62 \%)$ taking coated mesalazine and 28 of $43(65 \%)(p=0.438)$ taking sulphasalazine were pain free (table XIIm).

After eight weeks the mean (SD) pretrial endoscopic index decreased from $8 \cdot 6(2 \cdot 1)$ to $5 \cdot 2(3 \cdot 6)$ in patients taking the coated preparation and from $8 \cdot 7(2 \cdot 2)$ to $4 \cdot 3$ $(3 \cdot 5)$ in those treated with sulphasalazine. Of patients in the two groups subjected to endoscopy after eight 
TABLE VII - Remission rates (evidence of remission taken as a clinical activity index $\leqslant 4$ )

\begin{tabular}{|c|c|c|c|}
\hline & \multicolumn{2}{|c|}{ Treatment group } & \multirow{2}{*}{$\begin{array}{c}\text { Significance } \\
\text { (Cochran-Mantel- } \\
\text { Haenszel statistics) }\end{array}$} \\
\hline & Coated mesalazine & Sulphasalazine & \\
\hline \multicolumn{4}{|l|}{ Week 2: } \\
\hline Patients treated & 82 & 71 & \multirow{3}{*}{$0 \cdot 722$} \\
\hline No $(\%)$ in remission & $39(48)$ & $38(54)$ & \\
\hline $95 \%$ Confidence interval (\%) & $37 \cdot 1$ to $58 \cdot 2$ & $42 \cdot 0$ to $64 \cdot 6$ & \\
\hline \multicolumn{4}{|l|}{ Week 4: } \\
\hline Patients treated & 70 & & \multirow{3}{*}{0.338} \\
\hline No $(\%)$ in remission & $50(71)$ & $38(66)$ & \\
\hline 95\% Confidence interval (\%) & 59.9 to 80.6 & $52 \cdot 6$ to $76 \cdot 4$ & \\
\hline \multicolumn{4}{|l|}{ Week 6: } \\
\hline Patients treated & 60 & 48 & \multirow{3}{*}{$0 \cdot 859$} \\
\hline No $(\%)$ in remission & $41(68)$ & $36(75)$ & \\
\hline 95\% Confidence interval (\%) & $55 \cdot 7$ to $78 \cdot 6$ & $61 \cdot 2$ to $85 \cdot 0$ & \\
\hline \multicolumn{4}{|l|}{ Week 8: } \\
\hline Patients treated & 50 & 43 & \multirow{3}{*}{$0 \cdot 835$} \\
\hline No $(\%)$ in remission & $37(74)$ & $35(81)$ & \\
\hline 95\% Confidence interval (\%) & $60 \cdot 4$ to $84 \cdot 1$ & $67 \cdot 3$ to $90 \cdot 2$ & \\
\hline
\end{tabular}

weeks of treatment, 20 of $41(49 \%)$ and 18 of $38(47 \%)$ respectively had endoscopic scores of less than $4(p=$ $0 \cdot 272$ ) (table XIII).

Of the patients who discontinued the trial before completion, $16(18 \%)$ in the coated mesalazine treatment group and $12(16 \%)$ in the sulphasalazine treatment group did so because of inefficacy of treatment (table V).

\section{ADVERSE EFFECTS}

The most frequently occurring adverse events were hypersensitivity reactions - for example, pruritus and rash-headache, nausea and vomiting, and epigastric and abdominal pain. Though the incidence of headache and abdominal and epigastric pain was similar in the two treatment groups, four times as many patients taking sulphasalazine had hypersensitivity reactions

\section{MINIPRINT TABLES VIII-XII}
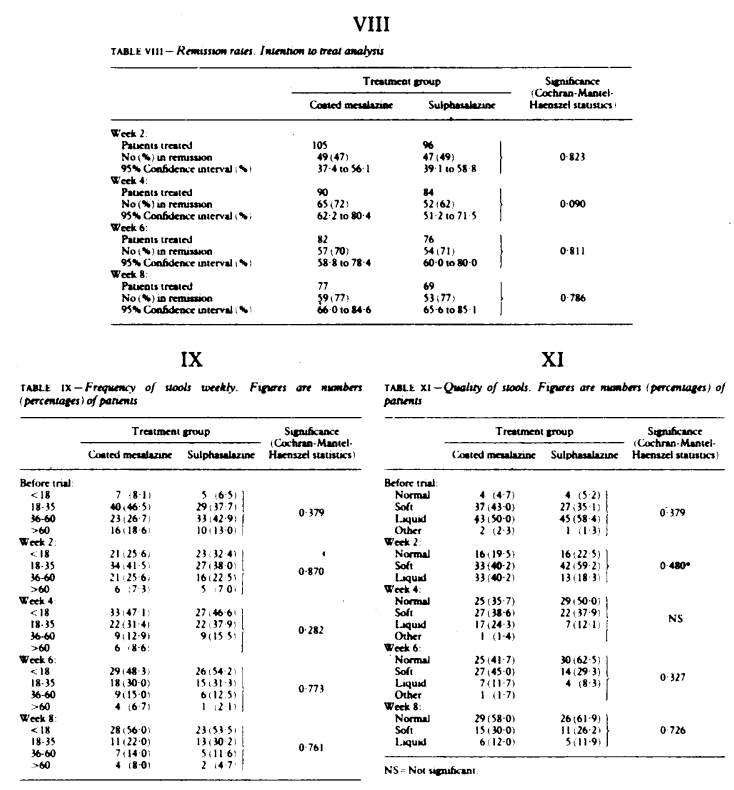

XII

$\mathrm{X}$
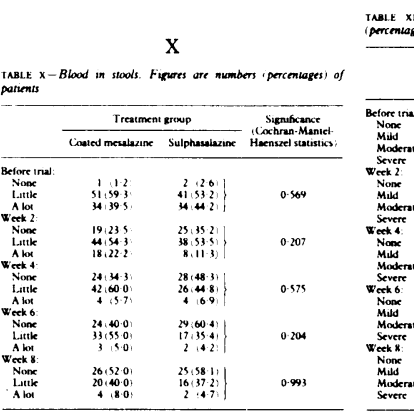

and episodes of nausea and vomiting (table XIV). Overall only 16 patients (14\%) in the coated mesalazine treatment group suffered adverse events as compared with $25(24 \%)$ in the group given sulphasalazine (table $\mathrm{XV})$. Seven patients $(6 \%)$ treated with coated mesalazine and $8(8 \%)$ given sulphasalazine were withdrawn from the trial because of adverse events. Six of the eight patients withdrawn from the sulphasalazine treatment group had hypersensitivity reactions (rash, pruritus, angioneurotic oedema), two needing admission to hospital. By contrast, only one patient taking coated mesalazine had to stop treatment because of pruritus. The remaining two patients withdrawn from the sulphasalazine treatment group suffered gastrointesti-

TABLE XIII - Endoscopic remissions at week 8

\begin{tabular}{|c|c|c|c|}
\hline & \multicolumn{2}{|c|}{ Treatment group } & \multirow{2}{*}{$\begin{array}{c}\text { Significance } \\
\text { (Cochran-Mantel- } \\
\text { Haenszel statistics) }\end{array}$} \\
\hline & $\begin{array}{l}\text { Coated } \\
\text { mesalazine }\end{array}$ & Sulphasalazine & \\
\hline $\begin{array}{l}\text { Patients treated } \\
\text { No }(\%) \text { in remission } \\
95 \% \text { Confidence } \\
\text { interval }(\%)\end{array}$ & $\begin{array}{l}41 \\
20(49) \\
34 \cdot 2 \text { to } 63 \cdot 5\end{array}$ & $\left.\begin{array}{l}38 \\
18(47) \\
32 \cdot 4 \text { to } 62 \cdot 7\end{array}\right\}$ & $0 \cdot 272$ \\
\hline
\end{tabular}

TABLE XIV-Incidence of most frequently occurring adverse events. Figures are numbers (percentages) of patients

\begin{tabular}{lcc}
\hline & \multicolumn{2}{c}{ Treatment group } \\
\cline { 2 - 3 } Adverse event & $\begin{array}{c}\text { Coated mesalazine } \\
(\mathbf{n}=115)\end{array}$ & $\begin{array}{c}\text { Sulphasalazine } \\
(\mathbf{n}=105)\end{array}$ \\
\hline Hypersensitivity reactions (rash, & & \\
pruritus, etc) & $3(2 \cdot 6)$ & $12(11 \cdot 4)$ \\
Nausea/vomiting & $2(1 \cdot 7)$ & $8(7 \cdot 6)$ \\
Headache & $4(3 \cdot 5)$ & $5(4 \cdot 8)$ \\
Abdominal/epigastric pain & $5(4 \cdot 3)$ & $3(2 \cdot 9)$ \\
\hline
\end{tabular}

TABLE $\mathrm{XV}$-Incidence of adverse events stratified by body system affected

\begin{tabular}{|c|c|c|}
\hline \multirow[b]{2}{*}{ Body system } & \multicolumn{2}{|c|}{ No of patients } \\
\hline & $\begin{array}{l}\text { Coated mesalazine } \\
\text { treatment group }\end{array}$ & $\begin{array}{l}\text { Sulphasalazine } \\
\text { treatment group }\end{array}$ \\
\hline \multicolumn{3}{|l|}{ General: } \\
\hline Eosinophilia & 1 & - \\
\hline Fever & 1 & 3 \\
\hline Fatigue & 1 & - \\
\hline \multicolumn{3}{|l|}{ Central nervous system: } \\
\hline Headache & 4 & 5 \\
\hline Paraesthesia & - & 2 \\
\hline \multicolumn{3}{|l|}{ Gastrointestinal: } \\
\hline Abdominal/epigastric pain & 5 & 3 \\
\hline Diarrhoea & 1 & - \\
\hline Heartburn & - & 2 \\
\hline Mouth dryness & - & 1 \\
\hline Nausea/vomiting & 2 & 8 \\
\hline Stomatitis & 1 & - \\
\hline \multicolumn{3}{|l|}{ Hepatic: } \\
\hline Cholestasis & 1 & - \\
\hline Hepatitis & 1 & - \\
\hline Hepatomegaly/jaundice & - & 1 \\
\hline Raised liver function values & 1 & 3 \\
\hline \multicolumn{3}{|l|}{ Musculoskeletal: } \\
\hline Joint pain/myalgia & 4 & - \\
\hline \multicolumn{3}{|l|}{ Psychiatric: } \\
\hline Depression & 1 & - \\
\hline \multicolumn{3}{|l|}{ Reproductive: } \\
\hline Irritation in penis & 1 & - \\
\hline Premenstrual oedema & - & 1 \\
\hline \multicolumn{3}{|l|}{ Respiratory: } \\
\hline Dyspnoea & 1 & - \\
\hline \multicolumn{3}{|l|}{ Skin: } \\
\hline Angioneurotic oedema & - & 2 \\
\hline Erythema/rash & 1 & 9 \\
\hline Pruritus & 2 & 6 \\
\hline \multicolumn{3}{|l|}{ Urinary: } \\
\hline Serum creatinine increased & - & 1 \\
\hline Total events & 29 & 47 \\
\hline \multirow{3}{*}{$\begin{array}{l}\text { Total No }(\%) \text { of patients with events } \\
\text { Total population } \\
\text { Total No }(\%) \text { of patients withdrawn } \\
\text { because of events }\end{array}$} & $16(14)$ & $25(24)$ \\
\hline & 115 & 105 \\
\hline & $7(6)$ & $8(8)$ \\
\hline
\end{tabular}

^Some patients experienced more than one event. 
nal events (vomiting, which necessitated admission, and epigastric pain). Of the seven patients withdrawn from coated mesalazine, one was admitted to hospital for acute pancreatitis after two days of treatment. Other events necessitating withdrawal of coated mesalazine were upper gastrointestinal complaints (nausea, epigastric pain), headache, eosinophilia, muscle fatigue, increased liver function values, and cholestasis.

\section{Discussion}

The aetiology of ulcerative colitis remains unknown and the goal of treatment is to control the inflammatory process without causing serious side effects. In this trial of a new, enteric coated preparation of mesalazine versus sulphasalazine patients with mild to moderately active disease achieved similar rates of remission (as measured clinically and endoscopically) after eight weeks of treatment. In addition, similar proportions of patients discontinued treatment because of therapeutic inefficacy. Coated mesalazine, however, was associated with substantially fewer adverse effects than recorded with sulphasalazine, patients in the sulphasalazine treatment group having four times as many hypersensitivity type reactions and episodes of nausea and vomiting.

We did not address the question whether patients intolerant of sulphasalazine can tolerate coated mesalazine. Cumulative data, however, suggest that most of these patients tolerate mesalazine, though a few may experience the same side effects. . $^{28-34}$

The therapeutic efficacy of $1.5 \mathrm{~g}$ coated mesalazine daily was similar to that of sulphasalazine $3.0 \mathrm{~g}$ daily. Clinical improvement or remission of mild to moderate exacerbations of disease was achieved in $86 \%,{ }^{35} 81 \%,{ }^{36}$ and $72 \%{ }^{37}$ of patients after four to seven weeks' treatment with $2.4 \mathrm{~g}$ daily of mesalazine coated with Eudragit $\mathrm{S}$. When a high dose $(4.8 \mathrm{~g} /$ day $)$ regimen of this preparation was compared with placebo pronounced efficacy and excellent tolerance were recorded in patients with mild to moderately active disease..$^{28}$ Olsalazine, another therapeutic modality designed to deliver 5-aminosalicylic acid to the colon, was shown to be valuable in mildly active ulcerative colitis ${ }^{32}$ and for maintaining remission. ${ }^{33}$ Though this compound was well tolerated by patients intolerant of or allergic to sulphasalazine, it induced diarrhoea necessitating withdrawal in about $10 \%$ of patients. ${ }^{33}$ Higher doses of mesalazine coated with Eudragit L may prove to be even more efficacious, and clinical trials with doses up to $4.0 \mathrm{~g}$ daily are warranted. We conclude that in patients with active mild to moderate ulcerative colitis the coated preparation of mesalazine as used in this trial is a safe, effective treatment.

The international study group consisted of the following investigators: Belgium - F Barbier, P Defrance, $M$ De Reuck, G Devis, M DeVos, A Elewaut, P H Potvin, P Rutgeerts, R Vanheuverzwyn, G Van Trappen; France $-M$ Bigard, R Camatte, M Cerf, R Colin, A Cortot, D Coumaros, J Gastard, D Labayle, H Lamouliatte, L Le Bodic, R Marti, J Pascal, J Rautureau, G Schenowitz, J Weill; Italy $-\mathrm{R}$ Caprilli, L Capurso, $M$ Cottone, P Dal Monte, G Dobrilla, R Galeazzi, $R$ Naccarato, L Pagliaro, C Prantera, G Riegler, F Rossini; Norway-S Barstad, B Boerkje, O Dahlberg, S Kildebo, K Nordgaard, A Skarstein; South Africa-S K Spies; Spain-J Berenguer Lapuerta, C Chantor, P de Las Casas, J de La Santa, A Solis-Herruzo, M Rodrigo-Moreno, L R RodrigoSaez, M Villagrasa.

1 Svartz N. Salazopyrin, a new sulfanilamide preparation. Acta Med Scand 1942;110:577-98
2 Svartz N. The treatment of 124 cases of ulcerative colitis with Salazopyrin and attempts at desensitization in cases of hypersensitivity to sulfa. Acta Med Scand 1948;206 (suppl):465-7).

3 Dissanayake AS, Truelove SC. A controlled therapeutic trial of long-term maintenance treatment of ulcerative colitis with sulphasalazine (Salazopyrin). Gut 1973;14:923-6.

4 Taffet SL, Das KM. Sulfasalazine-adverse effects and desensitization. Dig Dis Sci 1983;28:833-42.

5 Das KM, Eastwood MA, McManus JPA, Sircus W. Adverse reactions during salicylazosulfapyridine therapy and the relation with drug metabolism and acetylator phenotype. N Engl f Med 1973;289:491-5.

6 O'Morain C, Smethurst P, Dore CJ, Levi AJ. Reversible male infertility due to sulphasalazine in studies in man and rat. Gut 1984;25:1078-84.

7 Azad Khan AK, Piris J, Truelove SC. An experiment to determine the active therapeutic moietv of sulphasalazine. Lancet 1977;ii:892-5.

8 Campieri $M$, Lanfranchi GA, Bazzocchi G, et al. Treatment of ulcerative colitis with high-dose 5-aminosalicylic acid enemas. Lancet 1981;ii:270-1.

$9 \mathrm{Klotz}$ U, Maier K, Fischer C, Heinkel K. Therapeutic efficacy of sulfasalazin and its metabolites in patients with ulcerative colitis and Crohn's disease $N$ Engl f Med 1980;303:1499-1502.

10 Van Hees PAM, Bakker JH, van Tongeren JHM. Effect of sulphapyridine, 5 aminosalicylic acid, and placebo in patients with idiopathic proctitis: a study to determine the active therapeutic moiety of sulphasalazine. (Gut 1980;21 $632-5$.

11 Misiewicz JJ, Lennard-Jones JE, Connell AM, Baron JH, Jones FA. Controlled trial of sulphasalazine in maintenance therapy for ulcerative colitis. Lancet $1965 ;$; $: 185-8$.

12 Collins JT. Adverse reactions to salicylazosulfapyridine (Azulfidine) in the treatment of ulcerative colitis. South Med f 1968;61:354-8.

13 Gulley RM, Mizra A, Kelly CE. Hepatotoxicity of salicylazosulfapyridine: a case report and review of the literature. Am 7 Gastroenterol 1979;72:561-4

14 Han T, Chawla P, Sokal JE. Sulfapyridine-induced serum-sickness-like syndrome associated with plasmacytosis, lymphocytosis and multiclonal gammaglobulinopathy. $N$ Engl f Med 1969;280:547-8.

15 Jamshidi K, Arlander T, Garcia MC, Windschitl HW, Swaim WR. Azulfidine agranulocytosis with bone marrow megakaryocytosis, histiocytosis and plasmacytosis. Minn Med 1972;55:545-8.

16 Levi AJ, Fisher AM, Hughes K, Hendry WF. Male infertility due 10 sulphasalazine. Lancet 1979;ii:276-8.

17 Miller B. Nebenwirkungen der Therapie mit Salazosulfapyridin. Dtsch Med Wochenschr 1980;105:1596-7.

18 Pounder RE, Craven ER, Henthorn JS, Bannatyne JM. Red cell abnormalities associated with sulphasalazine maintenance therapy for ulcerative colicis. Gut 1975;16:181-5.

19 Singleton JW, Law DH, Kelley ML Jr, Makhiian HS, Sturdevant RAL. National cooperative Crohn's disease study. Adverse reactions to study National cooperative Crohn's disease s.
drugs. Gastroenterology 1977;77:870-82.

20 Lennard-Jones JR. Sulphasalazine in asymptomatic Crohn's disease. A multicentre trial. Giut 1977;18:69-72.

21 Ligumsky M, Karmeli F, Sharon P, Zor U, Cohen F, Rachmilewitz D). Enhanced thromboxane $A_{2}$ and prostacyclin production by cultured rectal mucosa in ulcerative colitis and its inhibition by steroids and by sulfasalazine. Gastroenterologv 1981;81:444-9.

22 Sharon P, Stenson WF. Enhanced synthesis of leukotriene $B_{4}$ by coloni mucosa in inflammatory bowel disease. Gastroenterologv 1984;86:453-60.

23 Peskar BM, Dreyling KW, Peskar BA, May B, Goebell H. Enhanced formation of sulfidopeptide-leukotrienes in ulcerative colitis and Crohn's disease: inhibition by sulfasalazine and 5-aminosalicylic acid. Agents Actions 1986;18:381-3.

24 Wengrower D, Eliakim R, Karmeli F, Razin E, Rachmilewitz D. Pathogenesis of ulcerative colitis: enhanced colonic formation of inositol phosphates and platelet activating factor [Abstract]. Gastroenterology 1987;92:1691.

25 Borgen L, Patel V, Powell D. A clinical pharmacologic study of 5 Borgen L, Patel V, Powell D. A clinical pharmacologic study
aminosalicylic acid oral dosage forms. Gastroenterology 1986;90:1351.

26 Hardy JG, Healey JNC, Reynolds JR. Evaluation of an enteric-coated delayedrelease 5-aminosalicylic acid tablet in patients with inflammatory bowe disease. Alimentary Pharmacology and Therapeutics 1987;1:273-80.

27 Dew MJ, Hughes PJ, Lee MG, et al. An oral preparation to release drugs in the human colon. Br $\mathcal{F}$ Clin Pharmacol 1982;14:405-8

28 Schroeder KW, Tremaine WJ, Ilstrup DM. Coated oral 5-aminosalicylic acid therapy for mildly to moderately active ulcerative colitis. $N \mathrm{Engl} f \mathrm{Med}$ 1987;317:1625-9.

29 Donald IP, Wilkinson SP. The value of 5-aminosalicylic acid in inflammatory bowel disease for patients intolerant or allergic to sulphasalazine. Postgrad Med f 1985;61:1047-8.

30 Schaffer JL, Kershaw A, Berrisford MH. Sulphasalazine-induced infertility reversed on transfer to 5 -aminosalicylic acid. Lancet $1984 ; 1: 1240$.

31 Dew MJ, Harries AD, Evans N, Evans BK, Rhodes J. Treatment of ulcerative colitis with oral 5 -aminosalicylic acid in patients unable to take sulphacolitis with oral 5-aminosal
salazine. Lancet 1983 ;ii:801.

32 Selby WS, Barr GD, Ireland A, Mason CH, Jewell DP. Olsalazine in active ulcerative colitis. Br Med f 1985;291:1373-5.

33 Sandberg-Gertzen $\mathrm{H}$, Jarnerot G, Kraaz W'. Azodisal sodium in the treatment of ulcerative colitis. Gastroenterology 1986;90:1024-30.

34 Habel FM, Greenberg GR. Treatment of ulcerative colitis with oral 5 aminosalicylic acid including patients with adverse reactions to sulfasalazine. Am F Gastroenterol 1988;83:15-9.

35 Mihas AA, Xynopoulos D, Mihas TA. A prospective trial of oral 5 aminosalicylic acid vs sulfasalazine in ulcerative colitis. Gastroenterologv 1988;94:A303.

36 Riley SA, Mani V, Goodman MJ, Herd ME, Dutt S, Turnberg LA Comparison of delaved release 5-aminosalicylic acid (mesalazine) and sulphasalazine in the treatment of mild to moderate ulcerative colitis relapse. Gut 1988;29:669-74

37 Barbara L, Bianchi Porro G, Biasco G. Oral 5-aminosalicylic acid (Asacol) in the treatment of active inflammatory bowel disease. An Italian co-operative the treatment of active inflammatory bowel disease. An Italian co-operative symposium, September 9-11, 1988. (In press.)

(Accepted 24 October 1988) 